\title{
Phototransformation of Linear Alkylbenzene Sulphonate (LAS) Surfactant Using ZnO-CuO Composite Photocatalyst
}

\author{
Rahadian Zainul*1, Jon Effendi², Mashuri Mashuri ${ }^{3}$ \\ ${ }^{1,3}$ Physical Chemistry Laboratory, Universitas Negeri Padang, Indonesia \\ ${ }^{2}$ Inorganic Chemistry Laboratory, Universitas Negeri Padang, Indonesia
}

\begin{abstract}
The aim of this study was to observe the effect of composition ratio of precursor and mass of $\mathrm{ZnO}-\mathrm{CuO}$ for photodegradation of Linear Alkylbenzene Sulphonate. Material synthesis is done by solid stated process. The $\mathrm{ZnO}-\mathrm{CuO}$ composite was characterized using DRS-UV and FTIR. The percentage of degradation was obtained from the absorbance value measured using a UV-Vis spectrophotometer. The $\mathrm{ZnO}-\mathrm{CuO}$ composite photodegradation activity in 2: 1 ratio was $54.71 \%$ for 105 minutes irradiation. The degradation percentage of $\mathrm{ZnO}-\mathrm{CuO}$ composites have higher photocatalytic activity than single $\mathrm{ZnO}(53.64 \%)$ and $\mathrm{CuO}(52.21 \%)$ semiconductors in degrading LAS.
\end{abstract}

Keywords: phototransformation, surfactant, LAS, composite, $\mathrm{ZnO}-\mathrm{CuO}$

E-mail : rahadianzmsiphd@yahoo.com

\section{Introduction}

Detergent is a cleaning material commonly used by industrial or household businesses. Detergent production continues to increase every year for cleaning agents[1]. Detergent is a combination of various compounds where the main component of the compound is surface active agents or surfactants. The most commonly used detergent surfactant is LAS or Linear Alkylbenzene Sulphonate[2].

LAS is an alkyl aryl sulphonate which has a branchless straight chain structure, a benzene ring and a sulphonate. LAS is the conversion of Alkylbenzene sulphonate or ABS, where LAS is more easily degraded in water and is a detergent 'soft' [3]. Detergent waste is one of the pollutants that can endanger the lives of organisms in the waters because it causes the supply of oxygen from the air to be very slow, due to the foam that covers the surface of the water [1].

Many technological methods are used to overcome this waste problem, such as chlorination, biodegradation and ozonation methods[4]. This method requires operational costs that are quite expensive so that it is less effective to be applied in Indonesia [5]. One method that is relatively inexpensive and easily applied in Indonesia, namely photodegradation. the principle is to use photocatalysts derived from semiconductor materials, such as $\mathrm{TiO}_{2}, \mathrm{ZnO}$ [6].

The application of photocatalysts as waste degradation agents has been widely carried out. The application of $\mathrm{ZnO}$ as a transformation of humic acid with the help of UV light [7,8]. Application in water spliting and as a promoter of the formation of electrical energy through visible light conversion techniques and water splitting $[9,10]$.

Zinc oxide semiconductors $(\mathrm{ZnO})$ are the best alternative choices after $\mathrm{TiO} 2$ semiconductors in their application as photocatalysts. The basic consideration is that the $\mathrm{ZnO}$ semiconductor is resistant to corrosion, has gap energy $(\mathrm{Eg}=3.2$ to $3.5 \mathrm{eV})$, and is much cheaper than $\mathrm{TiO}_{2}$. so that 
$\mathrm{ZnO}$ can be activated with UV (ultraviolet) radiation which results in low photocatalytic efficiency of $\mathrm{ZnO}$ in visible light. Increasing $\mathrm{ZnO}$ photocatalytic activity in visible light can be done by reducing $\mathrm{ZnO}$ energy bandgap by adding another semiconductor that has a narrow bandgap. $\mathrm{ZnO}$ incorporation has been carried out with other metal oxides and sulfides such as $\mathrm{TiO}_{2}, \mathrm{SnO}_{2}, \mathrm{WO}_{3}$, $\mathrm{NiO}, \mathrm{Fe}_{2} \mathrm{O}_{3}$, and $\mathrm{CuO}$ [11-15]. Copper (II) oxide $(\mathrm{CuO})$ was chosen because it is stable at the atmosphere, stable to light, low cost, and can cause a shift in absorption of $\mathrm{ZnO}$ in the direction of visible light [15-18].

Preparation of $\mathrm{ZnO}-\mathrm{CuO}$ nano-composites can be done by several methods including solid chemical synthesis method, coprecipitation, sol gel, and sonochemistry (sonochemistry). Sonochemical method (Ultrasonic Irradiation) is used to synthesize $\mathrm{ZnO}-\mathrm{CuO}$ nanocomposites because it has several advantages such as cheap, fast, easy to control size, low reaction temperature and the resulting particles have high homogeneity. Nanomaterial synthesis using sonochemical method is carried out using ultrasonic waves [19-22].

This research will be conducted to produce $\mathrm{ZnO}-\mathrm{CuO}$ composites which have high photocatalytic efficiency in visible light regions, compared to $\mathrm{ZnO}$ and $\mathrm{CuO}$ semiconductors. In this research, LAS compounds will be degraded with $\mathrm{ZnO}-\mathrm{CuO}$ composites to be able to be activated under visible light and reduce recombination reactions. This research will use LAS compounds as raw materials, $\mathrm{ZnO}-\mathrm{CuO}$ composite catalysts. The results of this study were analyzed using UV-vis spectrophotometer and the parameters measured were LAS concentration before and after the photocatalyst process.

\section{Experimental Section}

\subsection{Tools and Materials}

The tools used in this study are UV/Vis Spectrophotometer, Photocatalyst Box consisting of UV lamps and magnetic stirrer Selecta Multimatic brands, Ultrasonic (45 Hz) Ultrasonic Cleaner 968 brands, X-Ray diffraction (XRD), Fourier Infrared Transfers (FTIR), centrifuge, Oven brand $\mathrm{Xu} 225$ France Etuves, Neycraft brand furnace, Kern brand analytical balance, and glass equipment : measuring flask, beaker, dropper pipette and stirring rod. The material used in this study is zinc acetate dihydrate $\mathrm{Zn}\left(\mathrm{CH}_{3} \mathrm{COO}\right)_{2} .2 \mathrm{H}_{2} \mathrm{O}$ (Merck), $\mathrm{CuSO}_{4} .5 \mathrm{H}_{2} \mathrm{O}$ (Merck), $\mathrm{KOH}$ (Merck), ethanol, cetyltrimethylammonium bromide (CTAB, Merck), linear powder alkylbenzen sulphonate (LAS) (Merck), $\mathrm{ZnO}$ (Merck), $\mathrm{CuO}$ (Merck) and aquades.

\subsection{Procedure}

\subsection{1 $\mathrm{ZnO}-\mathrm{CuO}$ catalyst synthesis}

Mixed with $0.160 \mathrm{~g} \mathrm{Zn}\left(\mathrm{CH}_{3} \mathrm{COO}\right)_{2} .2 \mathrm{H}_{2} \mathrm{O}, 0.2497 \mathrm{~g} \mathrm{CuSO}_{4} .5 \mathrm{H}_{2} \mathrm{O}, 0.5611 \mathrm{~g} \mathrm{KOH}$ and $0.1093 \mathrm{~g}$ CTAB dissolved with distilled water to a volume of $30 \mathrm{~mL}$ solution. Then it was sterilized for 15 minutes. The mixture was heated at a temperature of $50^{\circ} \mathrm{C}$ and ultrasound at a frequency of $45 \mathrm{~Hz}$ for one hour. The mixture was then centrifuged at a speed of $5000 \mathrm{rpm}$ for 10 minutes, the filtrate was removed. The precipitate was washed with $30 \mathrm{~mL}$ of distilled water and $20 \mathrm{~mL}$ of absolute ethanol. The precipitate was dried in an oven at $120^{\circ} \mathrm{C}$ for 2 hours. Calcined at $50^{\circ} \mathrm{C}$ for 5 hours, by raising the temperature slowly from 200 for 30 minutes, 300 for 45 minutes, and temperature 400 for 60 minutes. The same procedure is also done by varying the ratio of the precursor composition, namely $\mathrm{Zn}\left(\mathrm{CH}_{3} \mathrm{COO}\right)_{2} .2 \mathrm{H}_{2} \mathrm{O}$ : $\mathrm{CuSO} 4$ (2:1, 3:1, 4:1, 5:1) [23].

\subsubsection{Sampel preparation}


As much as $1 \mathrm{~g}$ of LAS surfactant were weighed, then diluted with distilled water to $1 \mathrm{~L}$ $(1000 \mathrm{ppm})$. Then $10 \mathrm{ml}$ of mother liquor was taken $(1000 \mathrm{ppm})$ and diluted with distilled water to $1 \mathrm{~L}(10 \mathrm{ppm})$. The sample solution will be used in this study is a LAS solution with a concentration of $10 \mathrm{ppm}$.

\subsubsection{Characterization of $\mathrm{ZnO}-\mathrm{CuO}$ catalyst}

Characterization using UV-DRS was carried out to calculate the value of the full $\mathrm{ZnO}-\mathrm{CuO}$ catalyst. Then it was characterized by FTIR instrument which aims to find out the information on the location of the oxide peak in the resulting $\mathrm{ZnO}-\mathrm{CuO}$ catalyst.

\subsubsection{Test of photocatalytic activity for LAS degradation}

\subsubsection{Determination of Precusor Comparison and $\mathrm{ZnO}-\mathrm{CuO}$ catalyst optimum mass}

$40 \mathrm{~mL}$ of LAS solution containing $10 \mathrm{ppm}$ and added $10 \mathrm{mg}$ of $\mathrm{ZnO}-\mathrm{CuO}$ catalyst. then irradiated with a UV lamp for 2 hours while being distributed. Then the solution was centrifuged at $5000 \mathrm{rpm}$ for 10 minutes and the filtrate was separated. The absorbance of the filtrate was determined using a UV-Vis spectrophotometer at a wavelength of $200-300 \mathrm{~nm}$. The same procedure was carried out for the addition of 20, 30, 40, 50, $60 \mathrm{mg}$ of $\mathrm{ZnO}-\mathrm{CuO}$ catalyst (2: 1, 3: 1, 4: 1, 5: 1).

\subsubsection{Determination of optimum radiation time}

$40 \mathrm{~mL}$ of LAS solution containing $10 \mathrm{ppm}$ LAS and added catalyst $\mathrm{x} \mathrm{mg} \mathrm{ZnO}-\mathrm{CuO}(\mathrm{x}=$ optimum concentration) then cycled with UV light with a time variation of 75, 90, 105, 120, 135 and 150 minutes while being sterilized. Then the solution was centrifuged at $5000 \mathrm{rpm}$ for 10 minutes and the filtrate was separated. The absorbance of the filtrate was determined using a UVVis spectrophotometer at a wavelength of 200-300 nm.

\subsubsection{Determination of the Effect of Catalyst Types}

$40 \mathrm{~mL}$ of LAS solution containing $10 \mathrm{ppm}$ LAS and added with catalyst $\mathrm{x}$ mg $\mathrm{ZnO}-\mathrm{CuO}$ ( $\mathrm{x}=$ optimum concentration) then irradiated with a UV lamp for t minutes while being distributed. Then the solution was centrifuged at $5000 \mathrm{rpm}$ for 10 minutes and the filtrate was separated. The absorbance of the filtrate was determined using a UV-Vis spectrophotometer at a wavelength of 200-300 nm. The same procedure is also performed using $\mathrm{ZnO}$ and $\mathrm{CuO}$ catalysts. Then the optimum $\mathrm{ZnO}-\mathrm{CuO}$ catalyst with different conditions without distrirer, and without irradiation [24].

\section{Results and Discussion}

Analysis using UV-DRS was only carried out on pure $\mathrm{ZnO}$ samples and the $\mathrm{ZnO}-\mathrm{CuO}$ catalyst was synthesized, namely $\mathrm{ZnO}-\mathrm{CuO} 2: 1$ which is the maximum $\mathrm{ZnO}-\mathrm{CuO}$ catalyst sample seen from the results of LAS phototransformation as shown in Figure 5. From the sample test, $\%$ reflectance to wavelength. The data obtained will be processed to obtain an estimate of the band gap value of each sample. Where from the results obtained it can be seen how the effect of pure $\mathrm{ZnO}$ with synthesis catalyst is $\mathrm{ZnO}-\mathrm{CuO} 2: 1$ on the tire gap energy of each sample. The band gap graph of $\mathrm{ZnO}$ and $\mathrm{ZnO}-\mathrm{CuO} 2: 1$ is shown in Figure 1. 


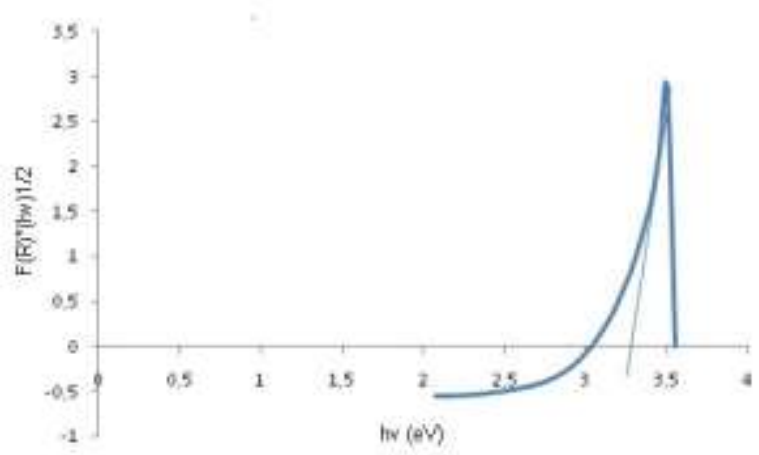

(a) $\mathrm{ZnO}$

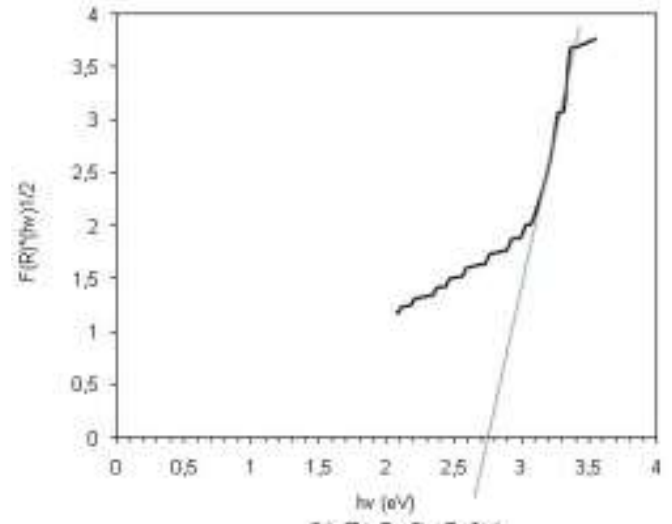

(b) $\mathrm{ZnO} \cdot \mathrm{CuO} 2: 1$

Figure 1. Graph of band gap values (a) $\mathrm{ZnO}$, (b) $\mathrm{ZnO}-\mathrm{CuO}$ 2: 1 using UV-DRS.

Band gap values from semiconductors can be calculated using the Kubelka-Munk theory. Band gap values of $\mathrm{ZnO}$ and $\mathrm{ZnO}-\mathrm{CuO} 2: 1$ are calculated from reflectance spectra. Based on Figure 4.10, it can be seen that the band gap values obtained for $\mathrm{ZnO} \sim 3.25 \mathrm{eV}$ and $\mathrm{ZnO}-\mathrm{CuO} 2$ : $1 \sim 2.75 \mathrm{eV}$. This shows that with the addition of another semiconductor, $\mathrm{CuO}$ on $\mathrm{ZnO}$ catalyst can reduce the band gap value. The small band gap value obtained in $\mathrm{ZnO}-\mathrm{CuO} 2$ : 1. This makes the photocatalytic activity more effective than other $\mathrm{ZnO}, \mathrm{CuO}$ and $\mathrm{ZnO}-\mathrm{CuO}$ composites.

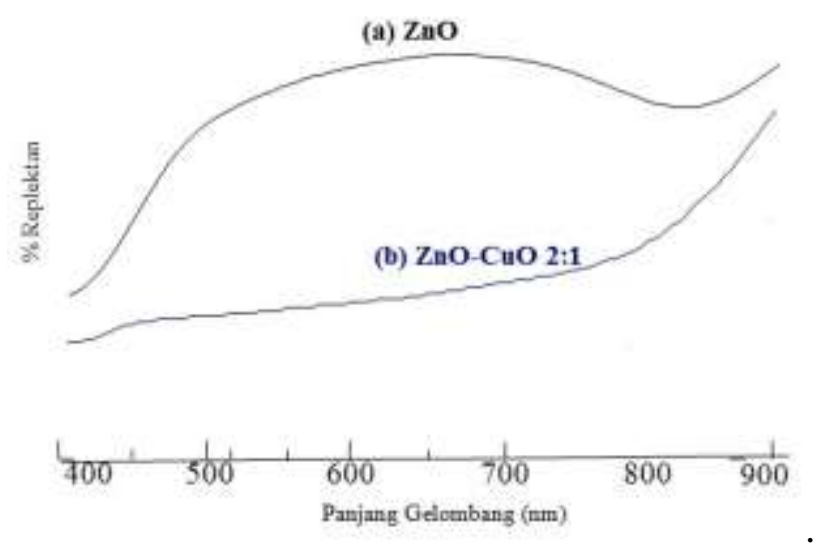

Figure 2. Reflectant spectra of catalysts: (a) $\mathrm{ZnO}$, and (b) $\mathrm{ZnO}-\mathrm{CuO}$ 2: 1 from UV-DRS Spectrophotometer 


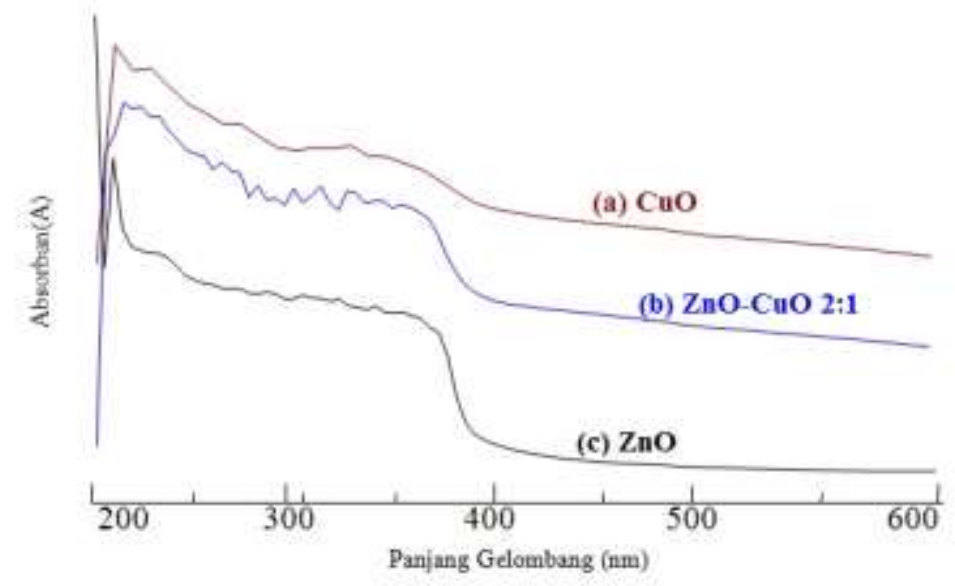

Figure 3. Spectral Absorbance of (a) $\mathrm{CuO}$, (b) $\mathrm{ZnO}-\mathrm{CuO} 2: 1$ and $\mathrm{ZnO}$ Catalysts from UV-DRS Spectrophotometers

From Figure 3, it can be seen that the incorporation of $\mathrm{ZnO}$ with $\mathrm{CuO}$ which has a narrow bandgap can reduce the $\mathrm{ZnO}$ bandgap itself so that the absorption of $\mathrm{ZnO}$ shifts to the visible light region.

In this study, FTIR analysis was carried out in pure $\mathrm{ZnO}$ catalyst samples, pure $\mathrm{CuO}$ as a comparison standard for the synthesis catalyst samples, $\mathrm{ZnO}-\mathrm{CuO}$. FTIR spectra of $\mathrm{ZnO}-\mathrm{CuO}$ catalyst can be seen in Figure 4.

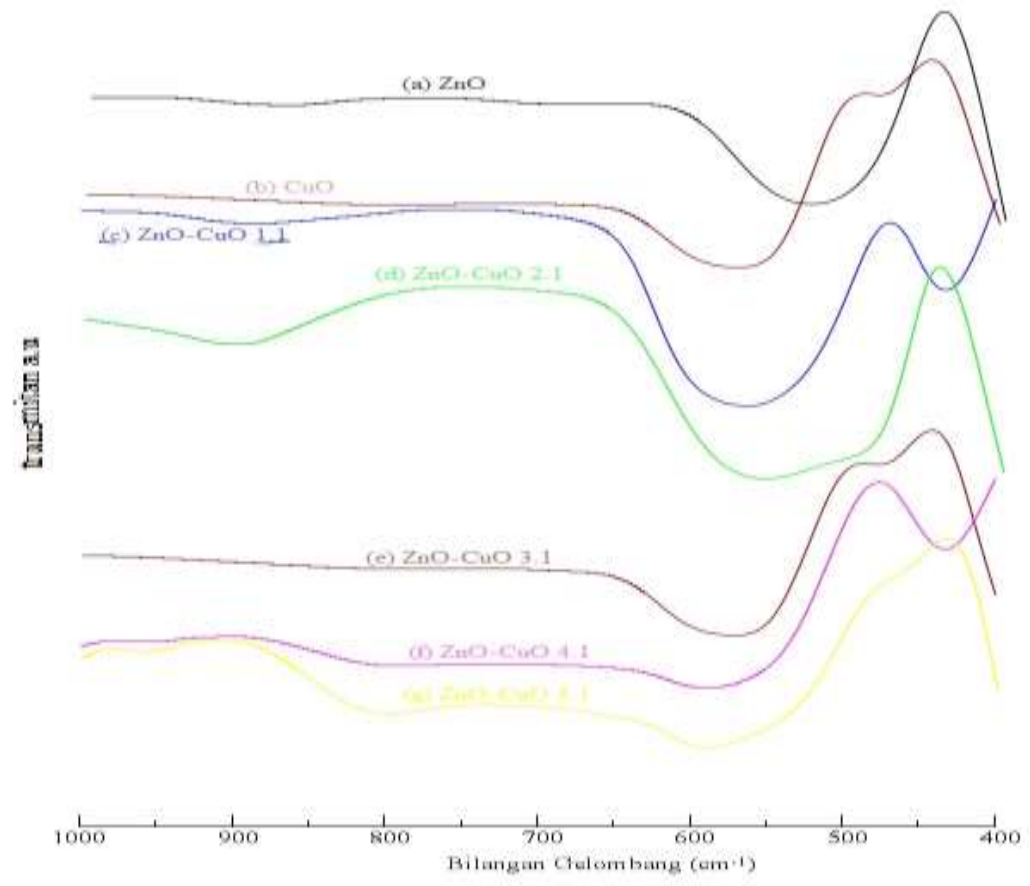

Figure 4. FTIR spectra of (a) $\mathrm{ZnO}$, (b) $\mathrm{CuO}$, (c) $\mathrm{ZnO}-\mathrm{CuO}$ 1.1, (d) $\mathrm{ZnO}-\mathrm{CuO} 2.1$, (e) $\mathrm{ZnO}-\mathrm{CuO} 3.1$, (f) $\mathrm{ZnO}-\mathrm{CuO} 4.1$, (g ) $\mathrm{ZnO}-\mathrm{CuO} 5.1$ 
From Figure 4, it can be seen that the synthesis catalyst $\mathrm{ZnO}-\mathrm{CuO} 2: 1$ shows that a new absorption band is formed which shows the stretching vibration of $\mathrm{ZnO}-\mathrm{CuO}$ composite metal oxide, while there is no other comparison formed $\mathrm{ZnO}-\mathrm{CuO}$ Composite but only vibrations are formed. $\mathrm{CuO}$ peak stretch. This is because the relative molecular period of $\mathrm{Zn}$ is greater than $\mathrm{Cu}$ which results in the formation of $\mathrm{CuO}$ peaks. in the wave number range $400-600 \mathrm{~nm}$ is the area of stretching of metal oxide oxide absorption [25].

$\mathrm{ZnO}-\mathrm{CuO}$ composites synthesized by different precursor comparison were tested for photocatalytic activity for LAS phototransformation. Figure 5 shows that several comparisons of the percentage of $\mathrm{ZnO}-\mathrm{CuO}$ composite catalysts from the results of phototransformation of LAS were carried out.

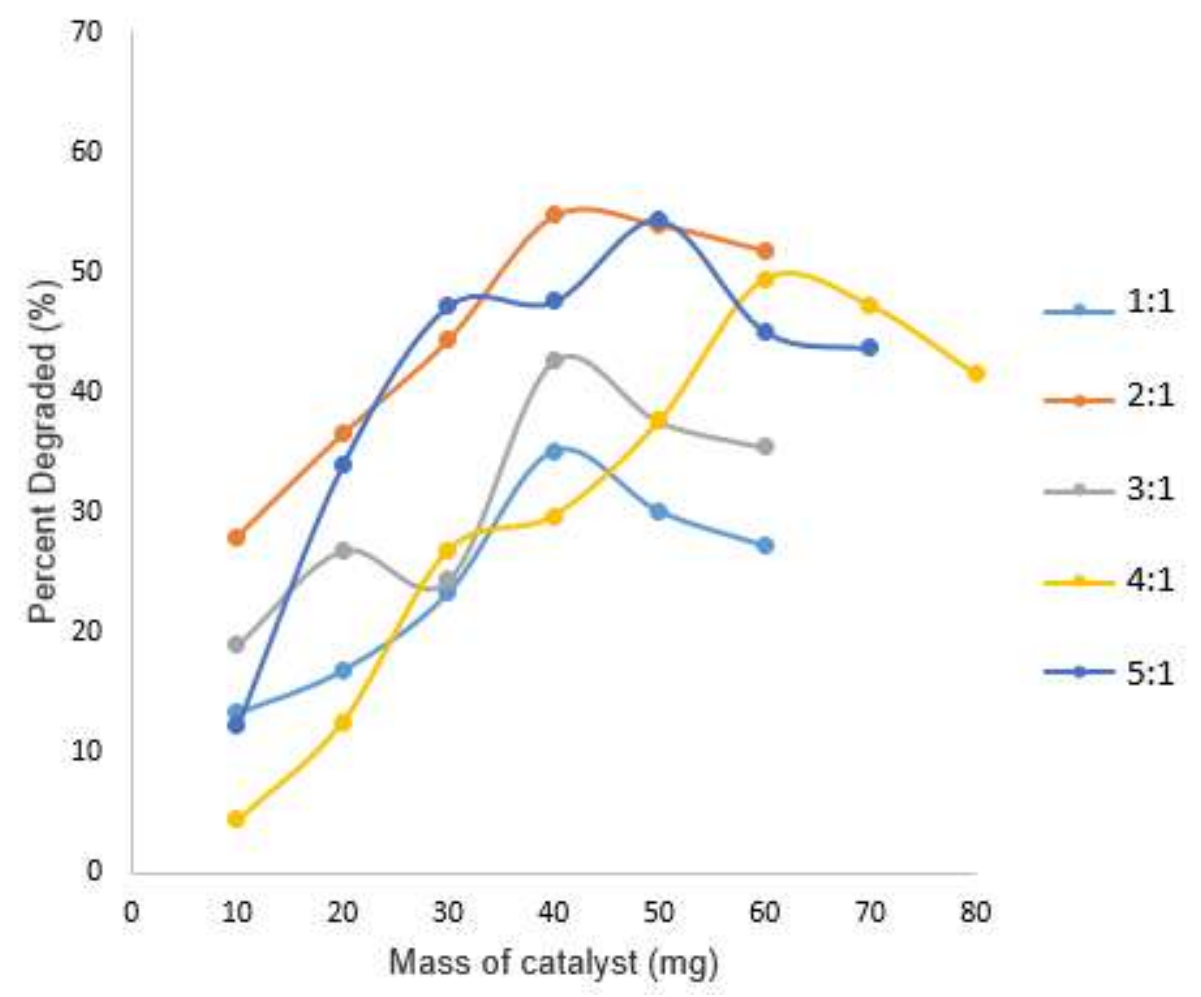

Fig 5. LAS degradation using variation of comparison of $\mathrm{ZnO}: \mathrm{CuO}$ catalysts

Comparison of precursor composition also affects the photocatalytic activity of $\mathrm{ZnO}-\mathrm{CuO}$ composites. The photocatalytic activity of $\mathrm{ZnO}-\mathrm{CuO}$ composites synthesized by the ratio of $\mathrm{Zn}$ $\left(\mathrm{CH}_{3} \mathrm{COO}\right)_{2} .2 \mathrm{H}_{2} \mathrm{O}: \mathrm{CuSO}_{4} .5 \mathrm{H}_{2} \mathrm{O}$ 2: 1 precursors was higher, ie $54.71 \%$ compared (1: 1, 3: 1, 4: 1, 5: 1) to Phototransformation of LAS. 


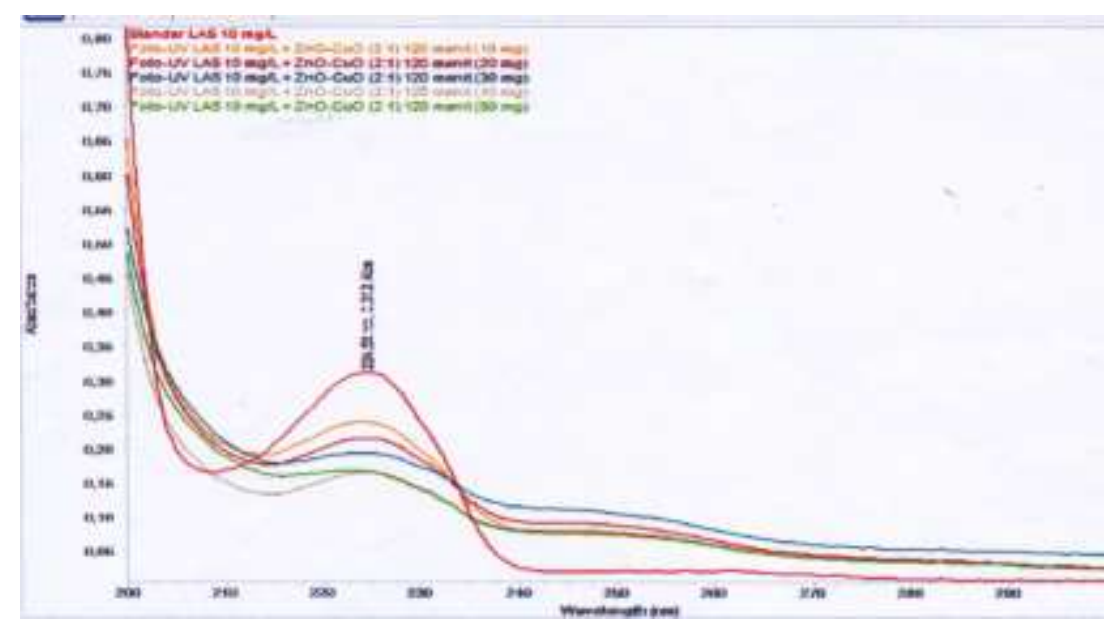

Figure 6. Spectrum of UV-vis spectrophotometer from 10 ppm LAS phototransformation results with $\mathrm{ZnO}-\mathrm{CuO}$ 2:1 catalyst

The amount of $\mathrm{ZnO}-\mathrm{CuO}$ 2:1 composite catalyst as much as $40 \mathrm{mg}$ in $40 \mathrm{ml}$ of $10 \mathrm{ppm}$ LAS solution becomes the saturation point or optimum conditions for the photocatalytic activity of $\mathrm{ZnO}-\mathrm{CuO}$ 2:1 composite (Figure 6). Larger precursor compositions cause higher levels of saturation of the solution so that the crystalline nucleus is formed too quickly so that the particle size will be greater because of the agglomeration of the formed crystal nucleus.

The crystal growth process will be different from and without surfactants. Cetyltrimethylammonium bromide (CTAB) surfactant can cause the surface tension between two liquids to decrease so that the energy needed to form a new phase will be smaller. CTAB is a cationic surfactant that will be fully ionized in water.

The calcination process carried out on the synthesis of $\mathrm{ZnO}-\mathrm{CuO}$ composites increased its photocatalytic activity. This increase in photocatalytic activity is caused by the decomposition of CTAB surfactants and the formation of crystals more completely when calcination occurs. Crystal structures predominantly affect semiconductor photocatalytic activity compared to morphology, particle size, and size dispersion [16,17].

Figure 7 shows that the percentage of degradation of the LAS solution. $\mathrm{ZnO}-\mathrm{CuO}$ shows a higher percentage than $\mathrm{ZnO}$ and $\mathrm{CuO}$ because $\mathrm{CuO}$ which is composited with $\mathrm{ZnO}$ can reduce bandgap energy. in $\mathrm{CuO}$ recombination $(\mathrm{e}-)$ and $\left(\mathrm{h}^{+}\right)$occur quickly. The incorporation of $\mathrm{CuO}$ with $\mathrm{ZnO}$ causes recombination time (e-) and $\left(\mathrm{h}^{+}\right)$to be slowed because of the transfer of charge between the two, namely $\mathrm{h}^{+}$on $\mathrm{ZnO}$ will be transferred to $\mathrm{CuO}$ and e- in $\mathrm{CuO}$ will be transferred to $\mathrm{ZnO}$ (Zhang., 2010). This causes the availability of sufficient time for LAS to be adsorbed on the surface of the $\mathrm{ZnO}-\mathrm{CuO}$ catalyst so that the photocatalytic activity is highest compared to the single $\mathrm{ZnO}$ and $\mathrm{CuO}$ semiconductors. 


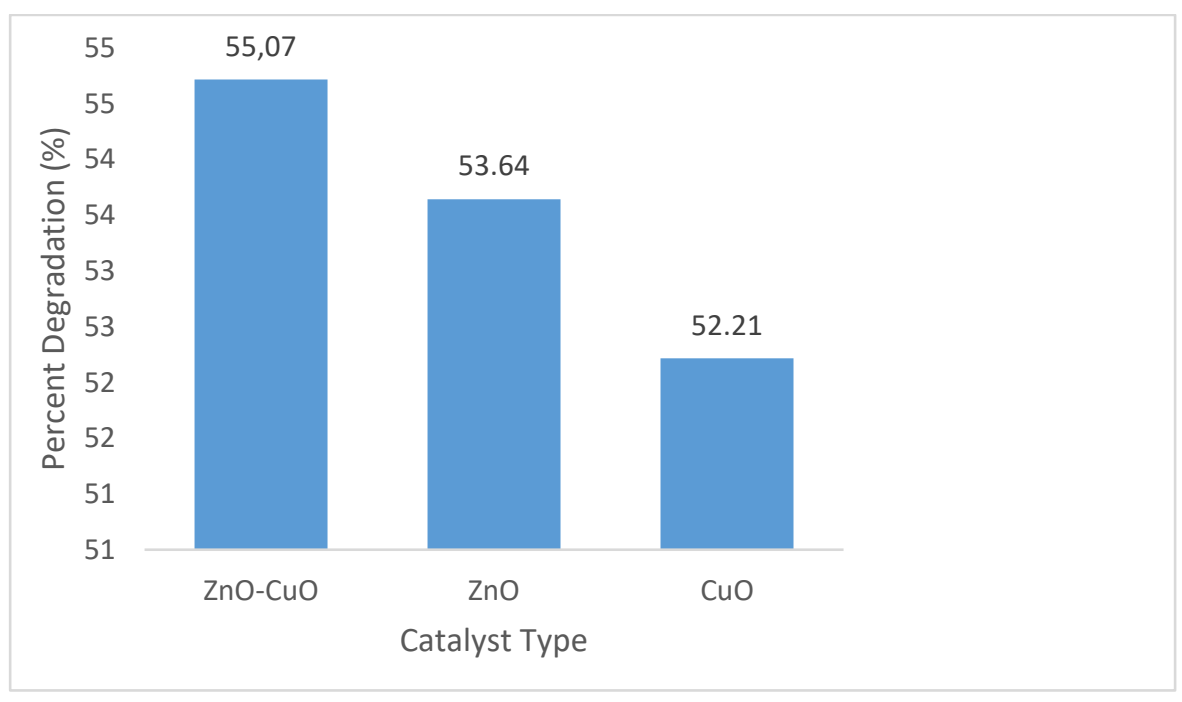

Figure 7. Effect of catalyst types on the percentage of LAS phototransformation

In the photocatalytic activity test, the $\mathrm{ZnO}-\mathrm{CuO}$ catalyst was carried out on the optimum catalyst mass of $40 \mathrm{mg}$ and the optimum time of irradiation was 105 minutes, where control was performed to see the possible effects of irradiation and stirring on LAS phototransformation. From the measurement results can be seen in the form of bar charts (figure 8) which shows that the effect of irradiation and stirring greatly affects the photocatalytic activity of the $\mathrm{ZnO}-\mathrm{CuO}$ catalyst in the LAS phototransformation process.

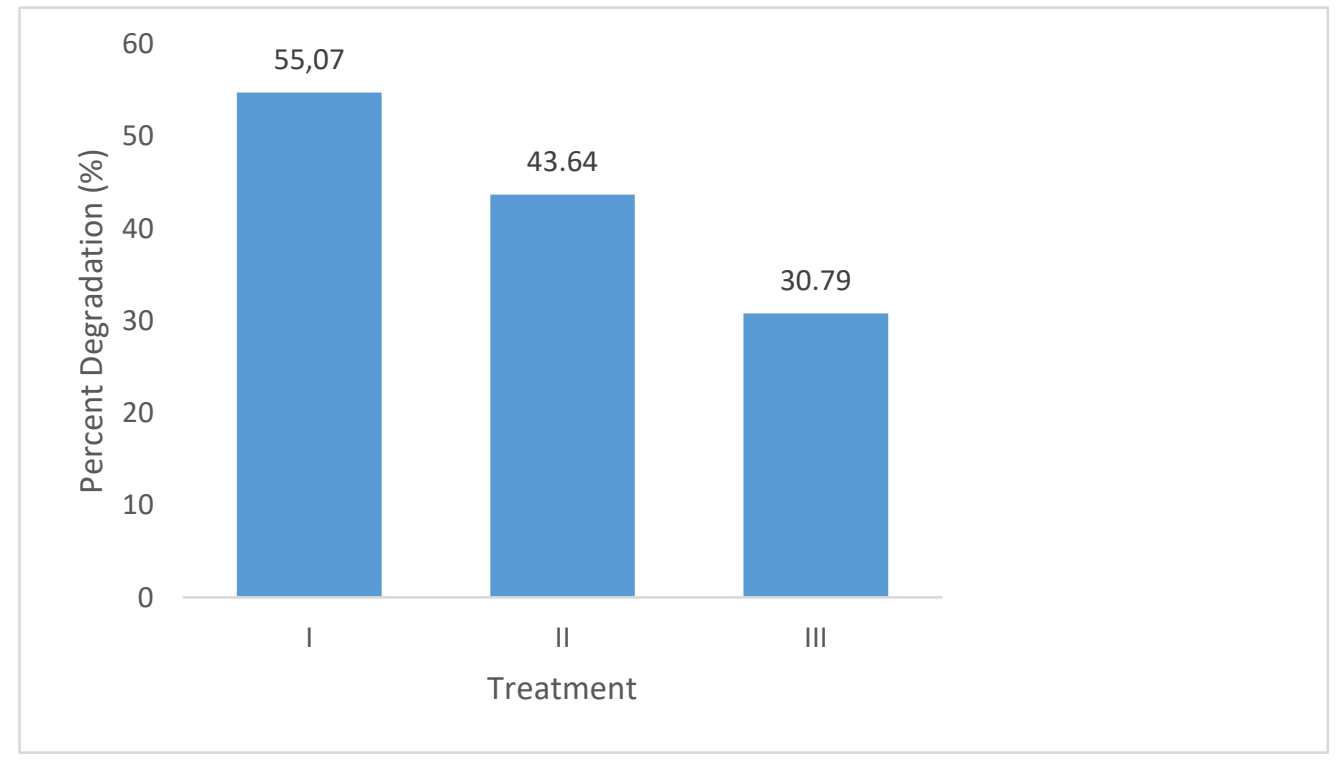

Figure 8. LAS phototransformation process with various treatments. Treatment I: optimum conditions (10 ppm LAS + $40 \mathrm{mg} \mathrm{ZnO}-\mathrm{CuO}$ irradiated while stirring for 105 minutes; b. Treatment II: $10 \mathrm{ppm}$ LAS + $40 \mathrm{mg} \mathrm{ZnO}-\mathrm{CuO}$ irradiated for 105 minutes without stirring ; c. Treatment III: 10 ppm LAS + $40 \mathrm{mg} \mathrm{ZnO-CuO} \mathrm{was}$ stirred for 105 minutes without irradiation. 
LAS phototransformation still occurs even without irradiation, this is because electron mobility still occurs even in dark conditions, the influence of room temperature can also induce photoconduction on the surface of the catalyst [23].

\section{Conclusion}

Based on the results of research that has been done, it can be concluded that the percentage of LAS degradation is higher in the precursor 2: 1 ratio of $54.71 \%$ with the optimum catalyst mass of $40 \mathrm{mg}$. The optimum time of copying for LAS degradation is at 105 minutes with a catalyst mass of $40 \mathrm{mg}$. The photocatalytic activity of $\mathrm{ZnO}-\mathrm{CuO}$ catalyst is higher in the percentage of degradation than the single $\mathrm{ZnO}$ and $\mathrm{CuO}$ semiconductors.

\section{Acknowlegdement}

Thank you the Government of the Republic of Indonesia, Ministry of Technology, Research and Higher Education on the Research Grand of Riset Unggulan Perguruan Tinggi in 2018-2019. Special thanks to the Rector of the Universitas Negeri Padang, has been facilitated and funded for Terapan Research in 2018, and Chemical Laboratory of Universitas Negeri Padang. Thanks to the research team of UNP Chemistry undergraduate students and the Research Team from Zainul for Advanced Material Processing (ZAMP).

\section{References}

[1] Connel D W, Miller G J 1995 Kimia dan Ekotoksikologi Pencemaran, UI-Press: Jakarta, Kimia dan Ekotoksikologi Pencemaran, UI-Press: Jakarta

[2] Supriyono E, Takashima F, Strussman C A 1998 Toxicity of LAS to Juvenile Kuruma Shrimp, Penaeus japonicus : A Histopathological Study On Acute and Subchronic Levels, Journal of Tokyo University of Fisheries, Japan 85 1-10

[3] Abel P D 1974 Toxicity of Synthetic Detergents to Fish aquatic Invertebrates, J.Fish, Biol

[4] Zulkarnain Chaidir, Desi Nurakbari, Marniati Salim, Zainul R 2016 Optimization of Spirulina Platensis Culture for Antioxidant Production, Der Pharmacia Lettre 8 73-78

[5] I. F, Sugiharto E, Wijaya K, Tahir I, Kamalia 2006 Titanium Oxide Dispered On Natural Zeolite (TiO2/Zeolite) And Its Application For Congo Red Photodegradation, Indonesian Journal of Chemistry 6 8-42

[6] Sakthivel S, Neppolian B, Shankar V, Arabindoo B, Palanichamy M, Murugesen V 2003 Solar Photocatalytic Degradation of Azo Dye Comparison of Photocatalytic Efficiency of $\mathrm{ZnO}$ and TiO2, Sol. Energy Mater. Sol. C 77 65-82

[7] Zainul R 2016 Effect of Temperature and Particle Motion Against the Ability of ZnO Semiconductor Photocatalyst in Humic Acid Der Pharmacia Lettre 8 pp. 120-124

[8] Zainul R 2016 Determination of the Half-Life and the Quantum Yield of $\mathrm{ZnO}$ Semiconductor Photocatalyst in Humic Acid Der Pharmacia Lettre 8 pp. 176-179

[9] Zainul R 2016 Design and Modification of Copper Oxide Electrodes for Improving Conversion Coefficient Indoor Lights (PV-Cell) Photocells Der Pharma Chemica 8 pp. 388-395

[10] Zainul R, Alif A, Aziz H, Arief S, Darajat S 2015 Modifikasi dan Karakteristik I-V Sel Fotovoltaik $\mathrm{Cu}_{2} \mathrm{O} / \mathrm{Cu}-\mathrm{Gel} \mathrm{Na}_{2} \mathrm{SO}_{4}$ Melalui Iluminasi Lampu Neon, Eksakta Berkala Ilmiah Bidang MIPA 15 50-56 
[11] An T, Liu X, Hu X, Sheng G, Fu J, Zhang M 2010 Preparation of a High-Activity $\mathrm{ZnO} / \mathrm{TiO} 2$ Photocatalyst via Homogeneous Hydrolysis with Low Temperature Crystallization Method, Materials Journal Letters 64 1883-1886

[12] Kowsari E, Ghezelbash M 2012 Ionic Liquid-Assisted Facile Synthesis of ZnO/SnO2 Nanocomposites and Investigation of Their Photocatalytic Activity, Journal of Matterial Letters 68 17-20

[13] Y. C, Kai Y, Qing S, Jimmy Y, Fangfang C, Xin L 2011 Preparation of WO3/ZnO Composite photocatalyst and Its Photocatalytic Performance, Chines Journal and Catalysis 32555-565 555-565

[14] Dm F, W.Hechenleitner, Silva M, Lima M, Bittencourt P, R.Silva, Melo M C, Pineda E 2009 Preparation and characterization of $\mathrm{NiO}, \mathrm{Fe} 2 \mathrm{O} 3, \mathrm{Ni} 0.04 \mathrm{Zn} 0.96 \mathrm{O}$ and Fe0.03Zn0.97O, Journal of Nano Materials. 118: 447-452 118 447-452

[15] Li B, Y.Wang Facile Synthesis and Photocatalytic Activity of ZnO-CuO Nanocomposite, Journal of Superlattices Microstructures 47 615-623

[16] Shouqiang W, S., Ma. Y C Y, Shao Z 2010 Fabrication of CuO/ZnO Composite Films with Cathodic co-Electrodeposition and Their Photocatalytic Performance, Journal of Molecules and Catalysis 331 112-116

[17] Liu Z, J.C.Deng., J.J.Deng, F.F.Li. 2008 Fabrication and Photocatalysis of CuO/ZnO Nano-Composites via a New MethodJournal of Material Science and Enginering, Journal of Material Science and Enginering 150 99-104

[18] Sathishkumar P, Sweena. R, Wu. J J, Anandan S 2011 Synthesis of CuO-ZnO Nanophotocatalyst for Visible Light Assisted Degradation of a Textile Dye in Aqueous Solution, Journal of Chemistry. Engineering 171 136-140

[19] Wongpisutpaisan, N. P C, N.Vittayakorn, W.Pecharapa 2011 Sonochemical Synthesis and Characterization of Copper Oxide Nanoparticles, Journal of Energy Procedia 9 404-409

[20] Wei Y, Chang P 2008 Characteristics of Nano Zinc Oxide Synthesized Under Ultrasonic Condition, Journal of Physics and Chemistry of Solids 69 688-692

[21] Xiao Q, Huang S, J.Zhang, C.Xiao, X.Tan 2008 Sonochemical Synthesis of ZnO Nanosheet, Journal of Alloy Compound 459 L18-L22

[22] Kas R, O.Birer 2012 Sonochemical Shape Control of Copper Hydroxysulfates, Journal of Ultrasound and Sonochemistry 19 692-700

[23] Kasuma N Y 2012 Penggunaan Komposit Zno-Cuo Yang Disintesis Secara Sonochemistry Yang Digunakan Sebagai Katalis Untuk Fotodegradasi Metil Orange Dan Zat Antibakteri, Tesis. Padang FMIPA Universitas Andalas

[24] Sanjaya H 2009 Fotodegradasi Sufaktan Linear Alkil Sulfonat (LAS) Menggunakan Sinar UV 254 nm Dengan Bantuan Semikonduktor ZnO Sebagai Fotokatalis, Laboratorium Kimia Lingkungan Program Studi Kimia Universitas Andalas

[25] Nakamoto K 1997 Infrares and Raman Specra of Inorganic and Coordination Compounds. 5th Edition, John and Sons, Inc. Canada Nasikin 